LI Leon (Orcid ID: 0000-0002-2865-6568)

\title{
CORPORATE GOVERNANCE AND CORRELATION IN CORPORATE DEFAULTS
}

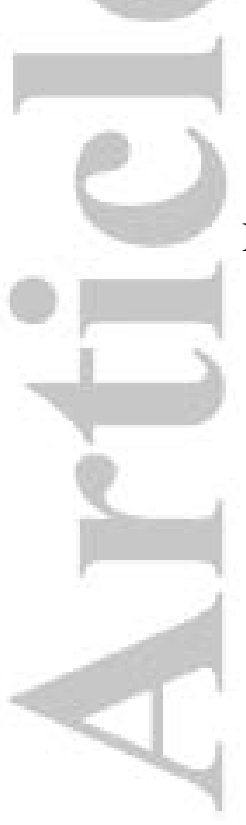

Jayasuriya Mahapatabendige Ruwani Fernando

Waikato Management School

University of Waikato, New Zealand

Phone Number: +64-7-856-2889 Ext. 9500

Department of Finance, Faculty of Commerce and Management Studies, University of Kelaniya, Sri Lanka.

E-mail: rf53@students.waikato.ac.nz,ruwani@kln.ac.lk

Leon $\mathrm{Li}^{*}$

Associate Professor of Finance

Subject Convenor, Finance

Waikato Management School

University of Waikato, New Zealand

Phone Number: +64-7-858-5650

E-mail: leonli@waikato.ac.nz

Yang (Greg) Hou

Senior Lecturer of Finance

Waikato Management School

University of Waikato, New Zealand

Phone Number: +64-7-856-2889 Ext. 9402

E-mail: greghou@waikato.ac.nz

October 2019

*: Correspondence author

This article has been accepted for publication and undergone full peer review but has not been through the copyediting, typesetting, pagination and proofreading process which may lead to differences between this version and the Version of Record. Please cite this article as doi: $10.1002 /$ corg. 12306 


\section{Abstract}

Manuscript Type: Empirical

Research Question/Issue: This study examines the effect of weak corporate governance in terms of concentrated ownership, low board effectiveness, low financial transparency and higher shareholder rights on default correlation when firms have different credit qualities.

Research Findings/Insights: Using historical default data in the United States from 2000 to 2015, we find that the degree of default correlation increases disproportionately for firms with concentrated ownership, low board effectiveness, low financial transparency and disclosures, and higher shareholder rights. More importantly, the effect of weak corporate governance on default correlation is high during a financial crisis.

Theoretical/ Academic Implications: This is one of the first studies testing the impact of corporate governance on the correlation in corporate defaults. It indicates new avenues of research for both corporate governance and credit risk management in relation to why joint default probabilities vary among firms.

Practitioner/ Policy Implications: Our results imply that good corporate governance is essential for credit risk management because poor corporate governance may increase individual default risk and create the domino effect of credit defaults. Practitioners and policy makers should enhance control over poor governance practices to reduce the probabilities of default. Moreover, the impact of corporate governance on correlation in corporate defaults is more pronounced in financial crises and warrants consideration from policy makers to take steps toward cushioning its effects.

Keywords: Default correlation, corporate governance, credit quality 


\section{INTRODUCTION}

Evaluating the default correlation among credit portfolios is a crucial process for bank credit risk management. Default correlation pertains to the relationship between a firm's individual default probability and the joint default probability among firms. Thus, the estimation of default correlation depends not only on the individual firm's default probability, but also on joint default probabilities among firms. For example, in a crisis, default correlation arises as a result of events of particular firm default and the collective default among firms. Researchers have identified cyclical correlation, the contagion effect, and learning from others as factors that cause joint default probabilities over the last few decades (Das et al., 2007). However, why joint default probabilities vary among firms is still under investigation. In this paper, we provide convincing reasons for the variations, based on the results of an empirical investigation of firms' corporate governance practices. Thus, we make theoretical contributions by testing the impact of corporate governance on corporate default correlation. In brief, we hypothesize that the degree of default correlation increases disproportionately for firms with weak corporate governance. The dynamic nature of default correlations due to corporate governance implies that weak corporate governance increases individual default risk and may also accompany a disproportionate increase in the credit risk of a portfolio.

The issue of correlation in corporate defaults has generated considerable interest and research has begun to focus on methodology and the examination of factors that cause defaults. Default correlations can be estimated by any one of three methods. The first method is to estimate default correlations based on asset correlations (e.g., Das et al., 2007). The second method is to use the credit default swap (CDS) or bond spread data (e.g., Jorion \& Zhang, 2007). The third method proposes using a standard binomial approach to measure default correlation based on realized historical default data (e.g., Lucas, 1995). Notably, default 
correlations have not been satisfactorily modelled. Lucas's method, which we adopt in this research, takes advantage of model-free estimation techniques (see Li \& Chen, 2018).

Factors that cause correlation in corporate defaults has attracted considerable research interest. Das et al. (2007) identify the three main reasons for default clustering as cyclical correlation, (Duffie, 1998; Keenan, 2000; Duffie et al., 2007); contagion effect (Aharony \& Swary, 1983; Lang \& Stulz, 1992; Giesecke, 2004); and learning from defaults (Jarrow \& Yu, 2001). A recent study by Li and Chen (2018) examines liquidity, systematic risk, and size as extensions of the three primary sources of default correlation proposed by Das et al. (2007).

This paper contributes by hypothesizing and examining the impact of corporate governance on the correlation in corporate defaults. Some extensive studies have been undertaken to test the effect of corporate governance on individual corporate defaults (see Daily \& Dalton, 1994). We have been unable to find any studies that systematically investigate the impact of corporate governance on correlations in corporate defaults. Following Standard and Poor's (2002) governance framework, we define four critical domains of corporate governance: ownership structure and influence, board effectiveness, financial transparency and disclosures, and shareholder rights. Accordingly, we develop four research hypotheses regarding the impact of corporate governance on correlations in corporate defaults. Our empirical results further indicate that default correlation is high for firms with concentrated ownership, low board effectiveness, low financial transparency and disclosures, and higher shareholder rights.

We follow the approach of Lucas (1995) by testing the impact of corporate governance on correlations in corporate defaults using the realised default data in the U.S. for the period between 2000 and 2015. In addition, following the studies of Lemmon and Lins (2003) and Erkens et al. (2012), both of which indicate that the effect of corporate governance on firm performance varies during a financial crisis, we retest our study to add a fifth hypothesis relating to defaults in both crisis and non-crisis periods. 
The results of this research can provide policy implications to banks and regulatory authorities. As hypothesized in this study, the degree of the domino effect of credit defaults increases disproportionately for firms with weak corporate governance, and the phenomena are more pronounced during crisis periods. Regulators should consider these findings and develop a viable regulatory capital framework for credit risk management to mitigate the potential consequences of underestimating default clustering due to poor corporate governance. Our empirical results imply that poor corporate governance might cause an increase in individual default risk and also exaggerate the domino effect of credit defaults. The increase in default correlations will, in turn, reveal an increase in portfolio credit risk. If the impact of corporate governance on default correlations is not given consideration, the benefit of reductions in risk stemming from credit portfolio diversification is likely to be overestimated for firms with weak corporate governance. Firms with weak corporate governance are associated with higher default correlations and, hence, are less effective in risk reduction if they are included in credit portfolio diversification efforts. Our findings support the argument that regulators should further adjust capital requirements for banks which provide loans to weak governance firms in crisis periods.

The rest of the paper is organized as follows. Section 2 reviews the literature on sources of default correlation and modelling for default correlations before developing the research hypotheses. Section 3 describes the sample and research design. Section 4 presents the results of the empirical findings. Section 5 presents the robustness tests undertaken in this study. Section 6 offers a conclusion and considers future directions for research.

\section{LITERATURE REVIEW AND HYPOTHESES DEVELOPMENT}

\section{Sources of Default Correlation}

There are three main reasons for default correlation: common factors or cyclical correlation, the contagion effect, and learning from others (Das et al., 2007). Cyclical 
correlation arises as a result of a similar pattern of correlated risk factors being present among firms. Common economic factors include interest rates, inflation, GDP, business cycles, and stock market performances. Duffie (1998) explains that the aggregate default rates are correlated because of general interest rate movements. Further, Duffie et al. (2007) find that personal income growth and term structure levels also affect the changes of default probabilities. De Servigny and Renault (2002) report that joint default probabilities are higher in recession periods than in non-recession periods. During a recession or a financial crisis, all businesses are adversely affected by their sensitivity to the general economic conditions. Li and Chen (2018) suggest that firms with a low beta, which represents the systematic risk, have high default correlation.

The contagion effect implies that one company's default induces the default of another company. ${ }^{i}$ For example, the default of a subsidiary company creates a default for its parent company. Accordingly, the default clustering phenomena are invariably observed between closely related companies with buyer-supplier relations. Initial studies on the contagion effect have focused mainly on stock market information (e.g., Lang \& Stulz, 1992) while later studies have investigated industry-related factors as the reason for the contagion effect. Among them, Jorion and Zhang (2007) recorded a positive correlation among credit derivatives due to the contagion effect and a negative correlation due to competition. According to them, the contagion effect is created among firms with similar cash flows ${ }^{\mathrm{ii}}$. Accordingly, Jorion and Zhang (2007) use equity, industry concentration, and leverage as ways to measure the correlation among bankruptcy firms and their competitors.

The third reason for default correlation is learning from defaults. For example, the failures of Worldcom and Enron highlight the importance of regulatory changes to firm irregularities which affect surviving companies (Das et al., 2007). Learning from others holds that the reason for one company's default could also exist in other companies; therefore, if 
these reasons are recognized or revealed, this could benefit the various stakeholders of other companies.

\section{Modelling Default Correlation}

There are different approaches for estimating default correlation. The first approach is to estimate the default correlation on a structural model based on assets correlation. The most popular method is Merton's (1974) model. An extension of this model is developed and tested by Black and Cox (1976). The Merton model demonstrates stock as a call option where the strike price equals the face value of debt payment. It identifies two common factors for firms defaulting, that is, a firm's debt ratio and volatility of assets. Based on this model, the default probability is transformed into a hazard rate. Geske (1977) generates the default correlation by using the hazard rate and the default probabilities from the model. However, this assumes that default only occurs at a single point in time (i.e., at maturity), which is unrealistic because some credit instruments may default more than once. Also, the default probability of a firm is recognized when the value of its assets falls below its debt. Zhou (2001) uses the implications of the asset return model to establish the default correlation. Yet, Das et al. (2006) suggest that asset volatility is more important than asset return in modelling default correlation.

The literature shows that cash flows and liquidity have significant effects on aggregating default risk. For example, Jorion and Zhang (2007) show that firms with similar cash flows have a positive default correlation due to a contagion effect. Li and Chen (2018) show that illiquid firms have high default correlation due to inefficient market pricing. Even though the prices and valuation of assets are used to measure the default correlation under the structural models, which allows for the capturing of a long-term effect, they do not consider the short-term liquidity position of the firms which has higher practical importance for measuring default risk. 
The second approach is called a reduced-form method which is based on default intensity. This is an implicit approach where some observable market information, such as swap spreads and prices of bonds, is used to generate the default probabilities (Li, 2000). Default intensities are derived by estimating a model based on state variables such as interest rates, credit spreads and company ratings relating to the changes of business cycles. Duffie et al. (2003) use this method to find the correlation among sovereign spreads. This approach assumes that although the default events are independent, the correlation arises through the common influence of the changes of the state variables. Jarrow and Yu (2001) extend this approach to gauge default clustering due to firm-specific risk factors such as counter-party risk. The above methods recognize the default probability based on credit losses due to credit downgrading.

An alternative approach proposed by Lucas (1995) estimates default correlation based on historical default data, using actual default probabilities. It takes advantage of model-free estimation techniques and has proven useful in modelling default correlations in practice. Using the same approach, Li (2000) introduces a 'copula framework' for default correlation, which solves the problem of joint distribution in a credit portfolio.

\section{Hypotheses development: Corporate governance attributes and default correlations}

Agency theory forms a part of the bigger picture of corporate governance and it suggests that the separation of ownership from management is a cost to the organization (Jensen \& Meckling, 1976). There are two types of agency conflicts, that is, the conflicts between managers and stakeholders, including shareholders and debtholders, and the conflicts between shareholders and debtholders. These two types of conflicts eventually increase default risk and reduce firm value. Agency cost is particularly extensive in the U.S. where the firms' ownership is diffused. The widespread share ownership requires managers to control the operations of the 
firms. Thus, manger-shareholder conflicts arise due to the self-serving behavior of managers taking precedence over the interests of other stakeholders.

The second conflict, between shareholders and debtholders, incurs the agency cost of debt. The value maximization objective of shareholders frequently conflicts with the interests of debtholders. Galai and Masulis (1976) and Jensen and Meckling (1976) show that shareholders engage in risk-shifting behavior. For example, shareholders of highly levered firms that suffer financial distress tend to undertake risky investments with negative net present value. Such actions could lead to issues involving the future cash flows of these firms and create uncertainties for debtholders.

The hypotheses of our study focus on examining the effect of corporate governance on default correlations. The literature on corporate governance and default risk establish that default firms are associated with weak corporate governance mechanisms. Bhojraj and Sengupta (2003) show that governance mechanisms have an impact on default risk by mitigating agency cost. Ashbaugh-Skaife et al. (2006) find that firms with stronger governance mechanisms enjoy higher credit ratings due to lower default risks.

In the following sections, we develop our hypotheses on the relationship between corporate governance and default correlation in terms of four important attributes: ownership structure and influence, board effectiveness, financial transparency and disclosures, and shareholders' rights. Most of the governance attributes we test in this study aim to reduce the two types of agency conflicts discussed and to ensure that the governance mechanisms provide independent monitoring of management and avoid managerial opportunism. We hypothesize that the default correlations are not homogenous across firms and that they could increase asymmetrically for firms with poor corporate governance attributes. 


\section{Ownership Structure and Influence.}

Generally, firms with dispersed ownership rely heavily on governance mechanisms to reduce managerial opportunistic behavior and agency costs. Strong corporate governance mechanisms should be able to protect the interests of all stakeholders including debtholders. However, the effectiveness of governance mechanisms varies depending on the firm's ownership structure and its influence. Ownership concentration can have a positive or negative impact on the organization (Jensen \& Meckling, 1976; Ashbaugh-Skaife et al., 2006). The positive effect stems from block-holders and institutional investors who have financial interests and independent views, and therefore they are expected to have a positive influence on company monitoring processes (Jensen \& Meckling, 1976; Shleifer \& Vishny, 1997). Thus, agency costs are lower in firms with concentrated ownership, implying low default risk and high credit quality.

However, concentrated ownership might be a challenge for management in performing their managerial functions for the betterment of all stakeholders. For example, Jensen and Meckling (1976) and Galai and Masulis (1976) introduce the problem of risk-shifting behavior from shareholders to debtholders in firms with concentrated ownership. Concentrated ownership is a structure that can influence management to invest in risky projects where the success of projects increases the wealth of shareholders, while bondholders equally bear the failure of the project. La Porta et al. (1999) and Claessens et al. (2000) point out that if the controlling shareholders have significantly higher voting rights than their cash flow rights, there is a negative effect on minority interests. Further, Shleifer and Vishny (1997) suggest that if ownership concentration exceeds a certain threshold, controlling shareholders try to increase their personal benefits at the expense of minority shareholders and debtholders. La Porta et al. (1999) and Johnson et al. (2000) further suggest that under concentrated ownership, poor corporate governance transfers the value from the firm to the controlling shareholders. The 
literature presents mixed findings on the relationship between concentrated ownership and firm credit quality. For example, Bhojraj and Sengupta (2003) find that firms with high institutional share ownership tend to have high credit ratings, which suggests a low default risk. Yet, Ashbaugh-Skaife et al. (2006) find that large shareholders have a negative effect on credit ratings. Further, Elloumi and Gueyie (2001), Parker et al. (2002) and Fernando et al. (2019) find that firms with concentrated ownership are more likely to default, suggesting poor credit quality. We employ the percentage of institutional ownership ${ }^{\text {iii }}$, the percentage of the five largest shareholders' ownership, and blockholdership to measure ownership structure and influence. Switzer et al. (2018) find that institutional share ownership negatively affects default risk. Erkens et al. (2012) find that concentrated institutional share ownership positively associates with risk-taking behavior before the financial crisis occurred during the period 20072009. Thus, we posit that the potential risk-shifting behavior of shareholders increases the default correlation among firms with concentrated ownership due to a cyclical effect.

Ashbaugh-Skaife et al. (2006) suggest that under the "management disciplining" hypothesis $^{\mathrm{iv}}$, ownership concentration reduces default risk and increases credit quality, whereas under the "wealth distribution" hypothesis", concentrated ownership increases default risk and reduces credit quality. Given the mixed findings and arguments about ownership structure and its influence on agency cost, our first hypothesis is non-directional:

Hypothesis 1. Firms with different ownership structures are associated with different levels of default correlation.

\section{Board Effectiveness}

An active board provides an independent view on management performance and is responsible for the effective governance of the firm (Simpson \& Gleason, 1999). It has also been observed that an effective board of directors should have greater independence (see, for example, Zahra \& Pearce, 1989). Board effectiveness includes factors such as board size, board 
composition, and leadership structure. To represent board effectiveness, we use board size, CEO duality, and the number of independent and external directors on the board. Resource dependency theory suggests that the board of directors is the mechanism for reducing environmental uncertainty (Pfeffer, 1972), and managing external dependencies (Pfeffer \& Salancik, 1978). Accordingly, it is expected that an effective board reduces the moral hazard problem and the agency cost of debt.

The first attribute of an effective board is the size of the board. Resource dependency theory suggests that a larger board brings a greater amount of experiences, skills, and views to the board table. A larger board creates barriers for insiders to exercise managerialism by better monitoring, which in turn reduces the risk of bankruptcy. Switzer et al. (2018) find that board size is positively associated with default risk. However, Lipton and Lorsh (1992) show that a larger board is less effective when considering issues of coordination and free-riding. Platt and Platt (2012) find that default firms are characterized by a small board and a few independent directors. Overall, there is no clear conclusion on the relation between board size and board effectiveness. However, based on resource dependency theory, we argue that a larger board is necessary to increase board effectiveness and to reduce default risk.

The second attribute we consider is CEO duality. Governance mechanisms are effective when there is greater independence among insiders. Dalton and Kesner (1987) argue that an effective board is created when one person does not hold the positions of board chairman and CEO simultaneously. Daily and Dalton (1994) and Ashbaugh-Skaife et al. (2006) suggest that CEO duality increases default risk. Lorsch (1989) further suggests that firms can effectively face a financial crisis when they have an independent board structure and the positions of the CEO and the board chairman are separate. On the other hand, CEO duality could enhance effectiveness since the CEO would have a greater awareness of what was happening with the organization compared to outsiders. Although Pathan (2009) finds a negative effect of CEO 
duality in relation to bank credit risk, we posit that firms with CEO duality possess reduced board effectiveness and increased credit risk. This is because board members are less likely to provide independent monitoring and control the managerialism.

The third element is board independence. We contend that the greater the independence of the board, the greater the board effectiveness because board independence is necessary to provide independent monitoring and to reduce managers' self-directed behaviors. Further, the literature shows that board independence has a significant effect on reducing a firm's default risk (Ashbaugh-Skaife et al., 2006, Switzer \& Wang, 2013), which suggests that board independence increases credit quality.

Further, the lack of board effectiveness could mean that firms are less exposed to growth opportunities. The literature clearly documents a positive relationship between firm performance and board effectiveness. ${ }^{\text {vi }}$ Thus, better firm performance provides benefits to all stakeholders, which increases credit quality. Given these reasons, we assume that firms with less effective boards will show high levels of default correlation because of the board's inability to adjust to external environmental shocks. Our hypothesis is as follows:

Hypothesis 2. Firms with ineffective boards are associated with high default correlations and, conversely, firms with highly effective boards are associated with low default correlations.

\section{Financial Transparency and Disclosures.}

Governance mechanisms should be able to ensure financial transparency to reduce information asymmetry between managers and all other stakeholders. Therefore, timely and adequate information helps shareholders and debt-holders to make appropriate financing decisions. Accordingly, we posit that firms with greater financial transparency have reduced management discretionary actions and increased value-relevant information. The quality of the audit committee, which has been measured by determining the independence of the audit 
committee and auditor opinions, serves as a proxy for financial transparency and disclosures in our study.

Financial transparency through an independent audit committee reduces fraudulent financial reporting, accounting irregularities (Dechow et al., 1996), and reduces overstatement of earnings (Klein, 2002). It also reduces information asymmetry and increases investor confidence (Ashbaugh-Skaife et al., 2006). The Sarbanes-Oxley Act of 2002 (SOX) requires every member of an audit committee to be independent. However, Choen et al. (2010) point out that there is substantial variation in the composition of audit committees and their effectiveness. Klein (2002) finds that audit committee independence significantly affects abnormal accruals whereas Bédard et al. (2004) find that 100 percent audit committee independence reduces aggressive earnings management.

Ensuring the reliability of financial information and reporting is an integral part of governance mechanisms. As a proxy for quality of disclosures, we use a dummy variable, coded as one if a firm receives unqualified opinion and zero otherwise. The literature shows that firms receiving a qualified auditor opinion tend to have higher accruals (e.g. Francis \& Krishnan 1999; Bradshaw, Richardson, \& Sloan 2001), suggesting higher managerial opportunism. Further, the literature on bankruptcy prediction also shows the effect of auditor opinion on default risk (e.g., Altman \& McGough, 1974; Lensberg, Eilifsen, \& McKee, 2006). Lensberg et al. (2006) point out that the most significant variable in their final model of bankruptcy prediction is the auditor's opinion, validating the value relevance information of auditor reports. In line with the aforementioned literature, we include a qualified auditor opinion to reflect low financial transparency and disclosures. We assume that the firms receiving a qualified auditor opinion reflect higher agency costs due to higher earnings management. 
If corporate governance ensures better monitoring and financial reporting, then it reduces managerial opportunism and enhances financial transparency and disclosures. Therefore, firms with low financial transparency are deemed to be firms with poor governing practices. Moreover, Sengupta (1998) finds that firms with higher disclosure ratings could enjoy the lower interest costs of issuing debt which suggests that higher financial transparency and disclosures reflecting higher credit quality. Hence, we assume that firms with low financial transparency reflect low credit quality. Thus, the potential information asymmetry and earnings management due to weak financial transparency and disclosures may increase the contagion effect on default correlation (being low credit quality firms). We propose the following hypothesis:

Hypothesis 3. Firms with high financial transparency and disclosures are associated with low default correlations and, conversely, firms with low financial transparency and disclosures are associated with high default correlations.

\section{Shareholder rights.}

The attribute of shareholder rights reflects the power balance between shareholders and management. The role of governance mechanisms within this attribute is to ensure that managers do not use their discretionary power to gain personal benefits. Another role is to ensure that shareholders' rights do not conflict with the interests of minority shareholders and bondholders. Many have argued that shareholders' rights relate to corporate governance. However, evidence of such a relationship, as reported in the extant literature, is inconclusive. Shleifer and Vishny (1997) find that if shareholders' rights are significant, this increases their ability to monitor managers' actions and reduces biases in financial reporting. Healy and Wahlen (1999) identify a lower level of shareholder rights with poor governing practices on the basis that this increases managerial opportunistic behavior for earnings management, and as a result, increases agency costs. Gompers et al. (2003) suggest that companies with stronger 
shareholders' rights have higher firm value, higher profits, and higher sales growth. Moreover, strong shareholders' rights can mitigate the opportunistic behaviors of managers, which may otherwise have a negative impact on firm value (Ashbaugh-Skaife et al., 2006). These studies support the view that higher shareholders' rights represents good corporate governance and reduces agency problems.

The conflict between shareholders and debtholders creates the agency cost of debt. If shareholders are given greater power to influence decisions involving ownership control and management changes, this can be detrimental to bondholders (FitchRatings, 2004). FitchRatings (2004) further indicates that granting more power to shareholders generates an undesirable influence on management, which adversely affects the bondholders and thus creates a negative impact on wealth distribution. Ashbaugh-Skaife et al. (2006) demonstrate that giving shareholders greater power leads to lower credit ratings because stronger shareholders' rights increases the risk of wealth transfers from bondholders to shareholders. Risk-shifting behavior may also become more overt if shareholders' rights play a dominating role over management, and agency costs of debt increases as a result. Klock et al. (2005) show that firms with higher shareholders' rights are associated with a higher cost of debt financing. Chava et al. (2008) find that firms with higher shareholder rights are charged with higher loan spreads.

The two proxies we use to measure shareholders rights are the powers to ratify the independent auditors and to approve the remuneration of executive management. ${ }^{\text {vii }}$ Coffee (2006) stresses that independent auditors are crucial in the corporate governance framework. The Sarbanes Oxley Act of 2002 stipulates that the audit committee is responsible for the appointment and oversight of the independent auditors. Dao et al. (2012) stress that most boards consist of management who hold a significant influence on the auditor appointment. Therefore, it is necessary that the shareholders ratify the auditor selection to ensure the chosen auditor 
matches the company size and its financial reporting needs. The literature shows that the final decision by shareholders in appointing an auditor brings benefits to organizations (Mayhew \& Pike, 2004; Dao et al., 2012). Based on this reasoning, we assume that higher shareholders' rights in terms of auditor ratification serve to ensure auditor independence and reduce the managerial opportunism that causes low credit quality.

Agency theory (Jensen \& Mackling, 1976) stresses that shareholders should be the agents to design the compensation of executive management. However, the widespread ownership of U.S. public companies provides an incentive for the board of directors to design executive compensation. Core et al. (1999) find that less effective boards result in excessive CEO compensation. ${ }^{\text {viii }}$ Further, Davis (2007) and Deane (2007) find that having input on pay decisions by shareholers ensures better alignment of the interests of owners and managers and enhances governance quality. Therefore, we assume that giving shareholders the rights to approve the remuneration of executive directors works to reduce compensation and to increase value to shareholders. Given the mixed evidence on the relationship between the level of shareholders' rights and corporate governance, our hypothesis is non-directional:

Hypotheis 4. Firms with different levels of shareholder rights are associated with different levels of default correlations.

\section{Corporate governance effect on default correlation in crisis and non-crisis}

\section{periods.}

Crouhy et al. (2000) and Gersbach and Lipponer (2003) show that default clustering is high in recessions. De Servigny and Renault (2002) find the default correlation among noninvestment grade firms is higher in a recession than those in a growth period. Further, Li and Chen (2018) reveal that firms with very low credit quality have a high correlation in the crisis period. Accordingly, we expect that the impact of weak corporate governance (i.e., ownership concentration, low board effectiveness, low financial transparency and disclosures, and higher 
shareholders' rights) on correlations in corporate defaults is more pronounced during crisis periods. In particular, during a financial crisis, financial institutions strive to constrain their credits in order to avoid liquidity problems, and this, in turn, increases the liquidity risk of corporate borrowers. Thus, we assume that firms with weak corporate governance face difficulties in reacting to environmental shocks. Hence, our hypothesis differentiates the impact of corporate governance on default clustering risk in crisis periods from that of non-crisis periods. Our hypothesis is thus proposed as:

Hypothesis 5. Firms with weak corporate governance practices have higher default correlation in a crisis period than in a non-crisis period.

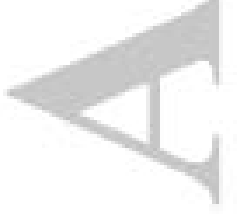

\section{RESEARCH METHOD AND DATA}

\section{Data}

In our study, the firms defined by the Compustat database as default firms over the period 2000-2015 are deemed as firms encountering bankruptcy or liquidation. Due to the infrequent nature of default events, it is necessary to control the number of non-default firms to minimize bias in the results caused by having a relatively small number of default firms. Accordingly, we couple the default firms with non-default firms by selecting five firms with the largest market capitalization from each industry using the first two digits of the Standard Industrial Classification (SIC) codes. The rationale for the non-default firms' selection criteria is that firms with the highest levels of market capitalization have a strong financial position with high credit quality and possess good corporate governance practices. Thus, our nondefault firms ensure that they necessarily differ from default firms in terms of credit quality and corporate governance practices. We exclude the financial firms (representing SIC codes 6000-6999) from the sample selection because of their different operating activities and capital structures. The final sample consists of 160 default and 675 non-default firm-year observations 
over the 2000-2015 period. We collect financial information from the Compustat database to calculate the credit quality of each firm. Equity prices are obtained from the Center for Research in Security Prices (CRSP) database. Corporate governance data are collected through company proxy statements and the Data Stream Database.

\section{Estimation of Default Correlation}

In order to test the default correlation, the different credit qualities of companies need to be recognized first. For this purpose, following Li and Chen (2018), we use the Altman (1968) Z-score model to measure the credit quality of firms. The five financial ratios -- sales to total assets, working capital to total assets, earnings before interest and tax to total assets, retained earnings to total assets, and market value of total assets to book value of total liabilities -- are used with the weights in the original Altman model. It is well documented in the literature that high credit rating firms imply a high score. After calculating the Z-score values, we define three credit ranges: high credit quality (Z-score $\geq 2.99)$, medium credit quality $(2.99<\mathrm{Z}$-score $\geq 1.81)$, and low credit quality $(\mathrm{Z}$-score $<1.81)$. These ranges are based on the original study by Altman (1968), where he identified 2.99 as the highest and 1.81 as the lowest value for recognizing bankrupt and non-bankrupt firms. A Z-score value above 2.99 clearly identifies a non-bankrupt firm and a Z-score below 1.81 denotes a bankrupt firm. The range between 1.81 and 2.99 is defined as a gray area in relation to bankruptcy.

We follow Lucas's (1995) approach to measure default correlation among firms with different credit qualities associated with corporate governance practices. Here, we briefly describe the procedure. Assume that there are two types of firms: firms A and B. We define $\mathrm{A}_{i}$ $(\mathrm{t})=1$ if firm $i$ defaults at time $\mathrm{t}$, and 0 otherwise. A represents default under high credit quality. Next, we define $\mathrm{B}_{i}(\mathrm{t})=1$ if firm $i$ defaults at time $\mathrm{t}$, and 0 otherwise. $\mathrm{B}$ represents default under low credit quality. The default correlation is thus computed as follows: 


$$
\text { Correlation }_{A B}(T)=\frac{P_{A B}(T)-P_{A}(T) \times P_{B}(T)}{\sqrt{P_{A}(T) \times P\left(1-P_{A}(T)\right)} \times \sqrt{P_{B}(T) \times P\left(1-P_{B}(T)\right)}}
$$

Where $P_{A}(T)$ and $P_{B}(T)$ represents the average default probabilities of high and low credit quality firms over $T$ years, i.e. total number of years. $P_{A B}(T)$ is the average joint default probability over $T$ years. Lucas (1995) suggests a standard binomial approach to estimate the individual and joint default probabilities based on a historical number of default data.

Let $N_{A(t)}$ and $N_{B(t)}$ be the total number of firms with high credit quality and low credit quality at time $t$, respectively. Thus, we define, $N_{A(t)}=N_{A, l}+N_{A, O}$, where $N_{A, l}$ is the total number of default firms with high credit quality at year $t$ and $N_{A, 0}$ is the total number of non-default firms with high credit quality in the same year. Accordingly, $N_{B(t)}=N_{B, 1}+N_{B, 0}$, where $N_{B, l}$ is the total number of default firms with low credit quality at year $t$ and $\mathrm{N}_{\mathrm{B}, 0}$ is the total number of non-default firms with low credit quality in the same year.

Following this method, the number of all possible pairs of high and low credit quality firms could be computed as $N_{A(t)} x N_{B(t)}$. Similarly, the number of all possible pairs of high, low and medium credit quality default firms is $N_{A(t), 1} \times N_{B(t), 1}$. Accordingly, the average joint default probability over $\mathrm{T}$ years among the high and low credit quality firms is:

$$
\begin{aligned}
& P_{A B}(\mathrm{~T}) \\
& =\frac{\left[\sum \frac{N_{A(t), 1} X N_{B(t), 1}}{N_{A(t)} X N_{B(t)}}\right]}{T}
\end{aligned}
$$

Following the same concept, we estimate the individual default probability for high credit quality and low credit quality firms as follows:

$$
\begin{aligned}
& P_{A}(\mathrm{~T}) \\
& =\frac{\left[\sum \frac{N_{A(t), 1}}{N_{A(t)}}\right]}{T}
\end{aligned}
$$




$$
P_{B}(\mathrm{~T})=\frac{\left[\sum \frac{N_{B}(t), 1}{N_{B(t)}}\right]}{T}
$$

\section{Research Design and the Construction of Governance Indices}

To test the hypotheses of asymmetric default correlation among firms with different levels of corporate governance, we develop indices for each governance dimension. To construct the indices for ownership structure and influence, board effectiveness, financial transparency and shareholder rights and relations, we consider eleven variables. The definitions and the research design for each index are outlined as follows.

a. Hypothesis 1, described in Section 2.3, tests the default correlation on concentrated/dispersed ownership. We use the ownership structure index to divide our sample firms into two subgroups: (1) concentrated ownership, and (2) dispersed ownership. The ownership structure and influence index is developed by using three variables: institutional share ownership (INS\%), shareholding by five major shareholders (FIVE_SH), and the existence of a major shareholder holding $20 \%$ of the total shares outstanding (BLOCK_20). A value of one is assigned to the index if the variables INS\% and FIVE_SH percentages are greater than 25\% and zero otherwise, which are criteria consistent with Wruck (1989). ${ }^{\text {ix }}$ BLOCK_20 is a dummy variable which equals one if the firm has a single shareholder with an ownership of $20 \%$ or above. La Porta et al. (1999) and Johnson et al. (2000) show concentrated ownership is riskier under poor corporate governance. We define the total index value to be the summed value of the three variables. Henceforth, dispersed ownership is defined as when the sum equals to zero or one, and concentrated ownership is defined as when the sum is equal to two or three (refer to Table 1 for variable definitions and Table 2 for indices development). Next, we estimate the default correlations separately for each 
subgroup within each pair of the three levels of credit quality, as described in Section 3.2 .

b. The second hypothesis is based on board effectiveness. Board effectiveness is measured through four variables: board size, CEO duality, number of independent (IND_DIRE) and outside directors (OUTS_DIRE) on the board. When these variables equal to 1, this indicates strong governance practice. 1 is assigned to the four variables in the following situations: the board size is equal to or greater than 12 (resource dependency theory suggests a larger board has greater experience); the CEO and the chairman is separate (Ashbaugh-Skaife et al. (2006) show that CEO duality increases default risk); the company's board comprises $75 \%$ or more of independent directors; and, of the total board, the percentage of outside directors is $75 \%$ or more (Switzer and Wang (2013) suggest that higher level of board independence increases credit quality). In otherwise situations, zero is assigned. ${ }^{\mathrm{x}}$ Accordingly, the index of board effectiveness takes the sum of the four variables. Firms are defined to have low board effectiveness when the index is 0,1 or 2 . If the index value is 3 or 4 , firms are defined to have high board effectiveness. ${ }^{\text {xi }}$ We then split our sample into two subgroups: (1) high board effectiveness, and (2) low board effectiveness. Next, we estimate the default correlations separately for each subgroup within each pair of the three levels of credit quality as described in Section 3.2.

c. Hypothesis 3 relates to financial transparency and disclosures. An index of financial transparency and disclosures is developed using two indicators: the audit committee quality (AUD_QUALITY) and the auditor opinion (AUD_OP). The audit committee quality equals to one if the audit committee is chaired by an independent director and zero otherwise. The auditor opinion equals to one if the company received unqualified opinion and 0 otherwise. Dechow et al. (1996) indicate that financial transparency via 
an independent audit committee reduces fraudulent financial reporting. Consequently, we expect a higher value of the index to represent good governance practice. If the sum of the summed index is zero or one, we categorize the firms as having low levels of financial transparency and disclosure; whereas if the summed index is equal to 2, the firms are categorized as ones with high levels of financial transparency and disclosure. Then we estimate the default correlations separately for each subgroup within the three levels of credit quality as described in Section 3.2.

d. To test the shareholder rights (Hypothesis 4), a shareholder rights index is constructed by using two indicators: shareholder rights to ratify the external auditor of the companies (EX_AUDITOR), and shareholder rights to approve the remuneration of the executive management (REM_MGT). The two variables are both dummy variables. EX_AUDITOR is one if the shareholders appoint the external auditor and zero otherwise. REM_MGT is one if shareholders approve the remuneration of the executive management and zero otherwise. Shleifer and Vishny (1997) indicate that enhanced shareholders' rights reduce biases in financial reporting and agency cost; thus, we assume higher shareholder rights to represent good governance. The firms are then categorized into those that either have high or low shareholder rights based on the total index value. If the summed index value is equal to 0 or 1 , this indicates low shareholders' rights; if the summed index value is equal to 2, the firms are categorized as having high shareholder rights. Next, we estimate the default correlations separately for each subgroup within each pair of the three levels of credit quality as described in Section 3.2.

e. To test the effect of corporate governance on default correlation in crisis and non-crisis periods (Hypothesis 5), we split the whole sample of firms into two groups under each dimension of corporate governance. For example, with respect to ownership 
concentration, we divide the whole sample into two subsamples: firms with concentrated ownership and firms with dispersed ownership. Then each subsample is divided further into two more subsamples of either crisis or non-crisis periods. Thus, the correlation is obtained for firm-groups with different levels of ownership and in different periods. The periods of 2001-2002 and 2007-2009 are deemed the crisis periods while the remaining periods are considered as non-crisis periods. We follow the same procedure of splitting the sample for the other dimensions.

\section{EMPIRICAL RESULTS}

\section{Descriptive Statistics}

Tables 3 and 4 summarize the descriptive statistics and correlations of the Z-score components and corporate governance variables, respectively. Panel A of Table 3 presents a comparative analysis of descriptive statistics between default and non-default firms for Z-score variables. Accordingly, non-default firms show higher mean values than default firms for all the ratios except for sales to total assets, indicating that the default firms have low working capital, market value, and earnings. Panel B of Table 3 reports the correlation among the Zscore components, which reveal no significant or high correlation.

Panel A of Table 4 provides a comparative analysis of the descriptive statistics between default and non-default firms for the governance variables. Default firms show higher mean values for ownership concentration variables. The proxies for board effectiveness are lower in default firms than in non-default firms in terms of having a small board, low levels of independence and few outside directors. With regard to financial transparency and disclosures, the mean value of the audit committee quality is low in the default firms. They also show a lower mean value for auditor opinion (low unqualified opinion ${ }^{\mathrm{xii}}$ ), indicating low financial transparency and disclosures. 
Shareholder rights and relations reveal a mixture of findings. Shareholder rights to ratify an external auditor in non-default firms is higher than in default firms. However, the shareholder right to approve the remuneration of executive management (REM_MGT) is higher in default firms than in non-default firms. All the proxies are significantly different between the two groups except for REM_MGT. The reason might be due to the inconclusive findings on shareholder rights as a determinant of credit quality (see, for example, AshbaughSkaife et al., 2006). Panel B of Table 4 reports the correlation among governance variables. All variables show low correlation except for independent director (IND_DIRE) and outside director (OUT_DIRE) variables. ${ }^{\text {xiii }}$

\section{Default Correlation among Credit Qualities over Different Time Horizons}

We examine the default correlation among firms with different credit qualities over one, five, and ten-year time horizons. As described in Section 3.3, the credit quality is derived by using the Z-score value. According to Table 5, a low default correlation is found for a one-year horizon. However, the default correlations in five-year and ten-year horizons are higher, particularly for firms with low credit quality. The result is consistent with previous findings (e.g., Crouhy et al., 2000; Zhou, 2001; Li \& Chen, 2018) which indicates that firms with low credit quality are unable to adjust to external environmental shocks, and they have less capacity to repay their loans than high credit quality firms.

\section{The Effect of Ownership Concentration}

Panel A of Table 6 shows the results of the impact of ownership concentration on default clustering. Default correlation among firms with concentrated ownership is higher than among those with dispersed ownership. Default correlation of high credit grade firms is lower for those with dispersed ownership, while the high credit grade firms in the concentrated ownership category show higher correlation. The default correlation among low credit grade firms with dispersed ownership concentration is $61 \%$, whereas the correlation of low credit 
grade firms with concentrated ownership is $75 \%$. Therefore, the result supports Hypothesis 1: Firms with concentrated ownership are associated with high default correlation and vice versa, firms with dispersed ownership are associated with low default correlation.

\section{The Effect of Board Effectiveness on Default Correlation}

We analyze the effect of board effectiveness on default clustering. Panel B of Table 6 reports the correlations among firms with low levels of board effectiveness and firms with highly effective boards. The comparative analysis indicates that firms with ineffective boards have higher default correlation than firms with highly effective boards. For example, low credit grade firms with low levels of board effectiveness show a 72\% correlation, whereas low credit grade firms with high levels of board effectiveness show only $58 \%$ correlation. High credit grade firms with boards that have high levels of effectiveness exhibit only $19 \%$ correlation; however, high credit grade firms with ineffective boards have $44 \%$ correlation. Thus, these empirical findings support Hypothesis 2: Firms with boards that show low levels of effectiveness are associated with high default correlation and, conversely, firms with highly effective boards are associated with low default correlation.

\section{The Effect of Financial Transparency and Disclosures}

Panel C of Table 6 presents the correlation results for low financial transparency and disclosures and high financial transparency and disclosures for firms with different credit grades. For each pair of grades, firms with low financial transparency and disclosures show higher default correlation. With respect to low levels of financial transparency and disclosures, a correlation of $71 \%$ is reported by low credit grade firms whereas medium and high credit grade firms have only $59 \%$ and $45 \%$ correlations, respectively. The correlations among the high, medium, and low credit grade firms with high financial transparency and disclosures are 25\%, 39\%, and 65\%, respectively. Hence, this result confirms Hypothesis 3, that is, firms with high financial transparency and disclosures are associated with low default correlation and, 
equally, firms with low financial transparency and disclosures are associated with high default correlation.

\section{The Effect of Shareholder Rights}

Panel D of Table 6 reveals that firms with high shareholder rights exhibit a higher default correlation compared to firms with low shareholder rights. The correlation among low credit grade firms with high shareholder rights is $75 \%$ while low credit grade firms with low shareholder rights show only a $64 \%$ correlation. More importantly, firms other than those with low credit grade show close correlation for both low and high shareholder rights.

This result is consistent with Ashbaugh-Skaife et al. (2006), who find a positive association between weaker shareholder rights and credit ratings. ${ }^{\mathrm{xiv}}$ This suggests that firms which place more power in their shareholders' hands have a negative effect on bondholders and this is viewed as detrimental by the credit rating agencies. Moreover, FitchRatings (2004) suggests that higher shareholders' rights are not necessarily considered as a good governing practice. Chava et al. (2008) also provide supporting evidence for our findings as their results indicate that banks charge higher interest to firms with higher shareholder rights than to firms with lower shareholder rights. They suggest that firms with higher shareholder rights have higher financial risk due to lower takeover defenses. Our results confirm that higher shareholder rights reduce the effectiveness of corporate governance mechanisms and companies with higher shareholder rights exhibit higher default correlation due to the contagion effect. Thus Hypothesis 4, which contends that firms with higher shareholders' rights are associated with high default correlations, is confirmed.

\section{The Effect of the Crisis on Default Correlation through Corporate Governance}

We test the effect of firm governance practices on default correlation in both periods of the financial crisis and non-crisis periods. Table 7 presents the results of the default correlations for the firms in both crisis and non-crisis periods under different levels of corporate governance 
practices. Panel A shows that firms with concentrated ownership have higher default correlation in both crisis periods $(17 \%)$ and non-crisis periods $(5 \%)$ and that the correlation is higher in the crisis period than in the non-crisis period. The default correlations among firms with low levels of board effectiveness in both crisis and non-crisis periods are $18 \%$ and $4 \%$, respectively, as indicated by Panel B. Firms with highly effective boards show a correlation of $14 \%$ in the crisis period and $5 \%$ in the non-crisis period. Panel $\mathrm{C}$ shows that the default correlation among firms with low financial transparency is higher in the crisis period (14\%) than in the non-crisis period $(2 \%)$. The respective default correlations for firms with high financial transparency are $11 \%$ in the crisis period and $1 \%$ in the non-crisis period. Panel D indicates that in the crisis period, the correlation among firms with higher shareholder rights is higher than firms with low shareholder rights (14\% for the former and $10 \%$ for the latter). However, the default correlation in non-crisis periods among firms with lower shareholder rights is high when compared to the other corporate governance dimensions. A reason for this might be that strong shareholder rights are perceived differently by different firms as either poor or good corporate governance, depending on the firm's specific context, such as its values, its credit rating level, and so on.

All the indicators of weak governance (ownership concentration, low levels of board effectiveness, low financial transparency and disclosures, and higher shareholder rights) show a higher default correlation in periods of crisis. As such, our fifth hypothesis, that firms with weak corporate governance practices have higher default correlation in a financial crisis period than in a non-crisis period, is accepted.

\section{Implications of the Findings}

The findings of this research have implications on credit portfolio management for banks and corporate financiers. A credit portfolio manager is concerned not only with an individual borrower defaulting but also with the possibility of multiple defaults in a portfolio. 
Therefore, it is necessary to recognize the sources behind correlated defaults among multiple firms. The findings of this study open a new discussion on refining the current strategies to reduce default risk in a portfolio in terms of corporate governance practices by firms. First, the hypothesis regarding ownership concentration confirms that firms with concentrated ownership reflect higher default correlation than firms with dispersed ownership. Therefore, when diversifying a credit portfolio to reduce potential credit losses, financiers should consider the ownership structure of a company and should allocate more funds to firms with dispersed ownership. It appears that the perceived benefit of reductions in risk stemming from credit portfolio diversification is likely to be overestimated for firms with weak corporate governance. This research also considers the impact of board effectiveness, financial transparency and disclosures, and shareholder rights because these governance dimensions also show a significant effect on default clustering probabilities. That is, if the credit portfolio consists of corporate borrowers having a less effective board, low financial transparency and disclosures, and high shareholder rights, the portfolio should be changed, or higher interest rates imposed to compensate for the high risk. Alternatively, the portfolio could be extended to select firms with more effective governance practices.

Furthermore, financiers should re-examine their portfolio in a crisis period as a higher default correlation exists in periods of crisis compared to non-crisis periods. In periods of crisis, financiers should be particularly careful when giving consideration to borrowers with high ownership concentration, a less effective board structure, and low financial transparency and disclosures. If banks are cognizant of the dynamic nature of the corporate governance practices of firms, they could create a high-return portfolio with effective controls for risks in place.

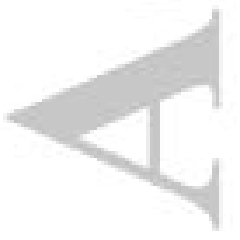




\section{ROBUSTNESS TEST}

We conduct various tests to check the robustness of our primary results. These tests use alternative measures of credit quality, financial transparency and shareholder rights. ${ }^{\mathrm{xv}}$

\section{Alternative Measurement for Credit Quality}

First, we use firm credit rating as an alternative measurement for credit quality. For this purpose, we use the long-term issuers' credit ratings compiled by Standard and Poor from the Compustat database. The credit ratings reflect the creditworthiness of the issuers' debt obligations. These ratings range from AAA (highest rating indicating lowest default risk) to D (lowest credit rating indicating highest default risk). For our analysis we divide the ratings into three categories, namely, high credit quality (from AAA to A-), medium credit quality (from $\mathrm{BBB}+$ to $\mathrm{B}-)$, and low credit quality $(\mathrm{CCC}+$ to $\mathrm{D}) .{ }^{\mathrm{xvi}}$ We retest the four hypotheses relating to corporate governance using these classifications of credit quality. Our empirical results (not tabulated) are consistent with the following notions. First, firms with concentrated ownership show a higher default correlation (75.32\%) than firms with diffused ownership (67.92\%). Second, firms with low levels of board effectiveness show a $73.53 \%$ correlation whereas firms with higher levels of board effectiveness have a $69.11 \%$ correlation. Third, firms with low financial transparency show a higher default correlation than those with high financial transparency (62.97\%). Lastly, firms with higher shareholder rights show a higher default correlation (73.64\%) compared to firms with low shareholder rights (72.64\%). All these results are significant at the $1 \%$ level. $^{\text {xvii }}$

\section{Alternative Measurement for Financial Transparency and Disclosures}

The second robustness test we conduct involves alternative proxies for financial transparency and disclosures. We use two new proxies for financial transparency: audit committee independence (measured by a binary variable which takes the value of one if the firm's audit committee comprises $100 \%$ and zero otherwise) and financial expertise (a binary 
variable that takes the value of one if the firm has at least one independent financial expert on the audit committee and zero otherwise). ${ }^{\text {xviii }}$ The variables are coded with 1 or 0 . Thus, if the summed index is 0 or 1 , we categorize the firms as ones with low financial transparency and disclosures; whereas if the summed index is equal to 2, the firms are categorized as having high financial transparency and disclosures. A firm needs to meet both criteria in order to be deemed highly transparent.

Our empirical results show that firms with low financial transparency tend to have a higher default correlation at the $1 \%$ significant level compared to those with high financial transparency. For example, a 74\% correlation is reported by firms with low financial transparency and disclosures and which have a low credit grade, whereas firms with high financial transparency and disclosures but which have a low credit grade show only a $48 \%$ correlation.

\section{Alternative Measurement for Shareholder Rights}

Finally, we employ an alternative measure for shareholder rights using the governance index (GOV_INDEX) used by Gompers et al. (2003). GOV_INDEX covers 24 provisions to measure the balance of power between investors and management. These are categorized into five areas: voting rights, tactics for delaying hostile bids, other takeover defenses, director/officer protection, and state takeover laws. According to Gompers et al. (2003), a higher score $(\mathrm{GOV}$ INDEX $\geq 14$ ) indicates higher managerial power and weaker shareholder rights. A lower score $(\mathrm{GOV}$ INDEX $\leq 5)$ indicates higher shareholder rights and lower managerial power. The median GOV_INDEX of our sample is 8 . Thus, we categorize the firms as having lower shareholder rights if the GOV_INDEX is greater than or equal to 8 . If the GOV_INDEX is less than 8, the firms are considered to possess higher shareholder rights. ${ }^{\text {xix }}$ The classification serves to maintain a balanced sample for each sub-group of shareholder rights dimension. Our empirical results (not tabulated) show that firms with higher shareholder 
rights tend to have a higher default correlation compared to those with lower shareholder rights. For example, the correlation among firms with a low credit grade and with high shareholder rights is $58 \%$, while firms with a low credit grade and with low shareholder rights show only a $50 \%$ correlation.

\section{The Issue of Endogeneity}

The problem of endogeneity is a major concern in empirical studies of accounting and finance issues. Bascle (2008) suggests three reasons for why endogenous problems occur: errors-in-variables, simultaneous causality, and omitted variables. To control the issue of errors-in-variables, we adopt a comprehensive framework for evaluating corporate governance that is based on four governance components: ownership structure and influence, board effectiveness, financial transparency and disclosures, and shareholder rights. Moreover, we use multiple proxies (two at least) for each governance component (see Table 1). To manage the issue of simultaneous causality, we collect the data of credit quality and corporate governance until the last available year before the time of the default event. Since the measures of the variables for corporate governance and credit quality come from earlier points in time than the default event, this design circumvents the issue of simultaneous causality.

To control the issue of omitted variables, we consider two additional variables (firm size and firm performance) to conduct two additional tests. Our points are presented below. First, the literature has documented the relation between governance structure and firm performance (e.g. Hermalin \& Weisbach, 1998; Wintoki et al., 2012). Moreover, Raheja (2005) and Harris and Raviv (2008) point out that firm performance influences the information environment and thus affects their governance structure. Second, Li and Chen (2018) indicate that small firms are associated with high default correlations. They argue that the market is less efficient for the stocks of small firms and market inefficiency increases the potential for mispricing which, in turn, could increase the contagion effect on default correlations. 
Following the literature, we hypothesize that firm size and firm performance might affect both corporate governance and corporate default correlation. Accordingly, we use firm size and firm performance to conduct two additional tests. First, firm size is proxied by the book value of total assets (e.g., Li \& Chen, 2018). Next, we use return on assets (ROA) as a proxy for firm performance (see Hermalin \& Weisbach, 1998). To test the impact of firm size on the relationship between corporate governance and corporate default correlation, we further divide the firms into two subgroup pairs: small versus large firms. Our empirical results (not tabulated) show that most small firms tend to have a higher default correlation along with poor governance characteristics (i.e., concentrated ownership, low financial transparency, and low board effectiveness). For example, the default correlation among firms with low board effectiveness increases from $30.06 \%$ in the large firm sample to $56.19 \%$ in the small firm sample.

Next, we employ ROA as a proxy for firm performance to examine the impact of firm performance on the relationship between corporate governance and corporate default correlation. To conduct the test, we use ROA to divide our sample into two subgroups: firms with low performance and firms with high performance. The empirical results (not tabulated) show that the relationship between corporate governance and corporate default correlation is more pronounced in firms with low performance. For instance, the default correlation among firms with concentrated ownership increases from $48.68 \%$ in the group of high performing firms to $67.29 \%$ in the group of low performing firms. Our conclusion is clear. The impact of corporate governance on corporate default correlation is more pronounced in small and lowperforming firms. These results demonstrate the joint effect of corporate governance, firm size, and firm performance on corporate default correlation. 


\section{CONCLUSION AND FUTURE RESEARCH DIRECTIONS}

This study addresses the effects of the corporate governance practices of firms on default correlations. Das et al. (2007) identify three causes of default correlations: cyclical effect, contagion effect, and the effect of learning from others. This paper contributes to the literature by extending the reasoning of Das et al. (2007). We find the corporate governance practices of firms significantly affect the clustered default risk among firms. We apply Lucas's (1995) method to test five hypotheses. The historical U.S. default data of 835 firm-year observations throughout the period from 2000 to 2015 is employed for the analysis. First, we find that firms with concentrated ownership are associated with high default correlation and firms with dispersed ownership are associated with low default correlation. Second, firms with ineffective boards are associated with high default correlation while low default correlation is apparent in firms with highly effective boards. Third, firms with low financial transparency are associated with high default correlation and conversely, firms with high financial transparency are associated with low default correlation. Fourth, strong shareholder rights create high default correlation among firms whereas firms with weaker shareholder rights are associated with low default correlation. Fifth, firms with weaker corporate governance practices have higher default correlation in a crisis period than in a non-crisis period. Our results imply that firms with weak corporate governance may have high default correlations and, hence, they could be less effective in risk reduction if included in a credit portfolio for diversification tasks.

This research has implications for financiers, and regulatory authorities. We recommend financiers consider corporate governance information for portfolio credit risk management. They should closely monitor firms with concentrated ownership, low board effectiveness, low financial transparency, and high shareholder rights. Overall, our findings indicate that regulators should adjust the capital requirements for banks that give loans to firms with weak governance during crisis periods. 
Our empirical results should, however, be interpreted with caution. First, the results are limited by the selection of variables. Although we conduct several robustness tests using alternative measures of credit quality and corporate governance, some other proxies might be used for the firm characteristics. Second, Lucas's (1995) method for default correlation, which we adopt in this paper, takes advantage of model-free estimation techniques and measures default correlation based on the realized historical default data. Since there are a few ways to estimate default correlations, it would be of academic interest to determine if this method is superior, because default correlations have not always been satisfactorily modeled, and each method has its own merits and disadvantages. Third, given the importance of cash flows and liquidity, future studies may examine the credit quality of firms using those two criteria, Potentially, if board diversity were used as a proxy for board effectiveness, this might also make the results more interesting.

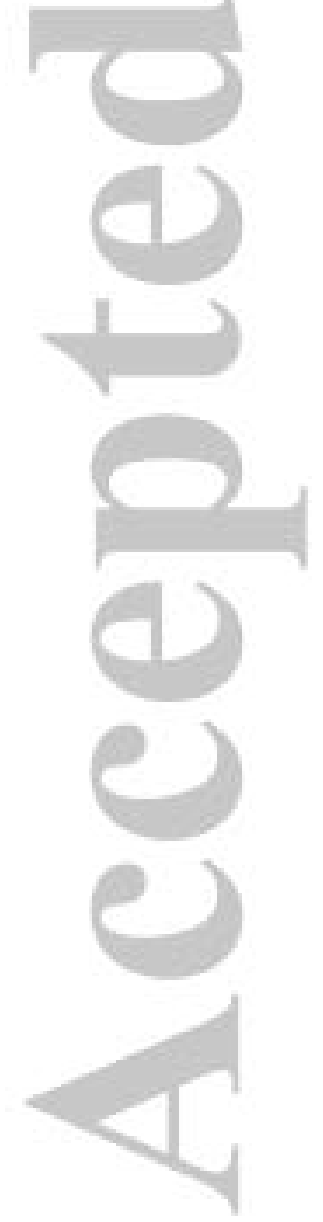




\section{TABLE 1}

\section{Definitions for Governance Indicators}

\begin{tabular}{|c|c|}
\hline Indicator & Definition \\
\hline \multicolumn{2}{|c|}{ Ownership structure and influence } \\
\hline INS_SH & Percentage of share ownership by institutions \\
\hline FIVE_SH & $\begin{array}{l}\text { Percentage of share ownership by five largest } \\
\text { shareholders }\end{array}$ \\
\hline BLOCK_20 & $\begin{array}{l}1=\text { if at least one shareholder has more than } 20 \% \\
\text { shares, } 0=\text { otherwise }\end{array}$ \\
\hline \multicolumn{2}{|l|}{ Board effectiveness } \\
\hline BOARD_SIZE & Number of board members in the board \\
\hline CEO_DUA & $\begin{array}{l}1=\text { if } \mathrm{CEO} \text { and Chair are the same person, } 0= \\
\text { otherwise }\end{array}$ \\
\hline IND_DIRE & Number of independent directors \\
\hline OUTS_DIRE & Number of outside directors \\
\hline \multicolumn{2}{|c|}{ Financial transparency and disclosures } \\
\hline AUD_QUALITY & $\begin{array}{l}1=\text { if audit committee chair is an independent } \\
\text { director, } 0=\text { otherwise }\end{array}$ \\
\hline AUD_OP & $1=$ if the opinion is unqualified, $0=$ otherwise \\
\hline \multicolumn{2}{|l|}{ Shareholder rights } \\
\hline EX_AUDITOR & $\begin{array}{l}1=\text { if shareholders appoint the external auditor, } 0= \\
\text { otherwise }\end{array}$ \\
\hline REM_MGT & $\begin{array}{l}1=\text { if shareholders approve the remuneration of } \\
\text { management, } 0=\text { otherwise }\end{array}$ \\
\hline
\end{tabular}


TABLE 2

Construction of Indices for Governance Dimensions

\begin{tabular}{|c|c|c|}
\hline Indicators & criteria for the indices & Construction of the indices \\
\hline \multicolumn{3}{|c|}{ Ownership structure and influence } \\
\hline $\begin{array}{l}\text { INS_SH } \\
\text { FIVESH } \\
\text { BLOCK }\end{array}$ & $\begin{array}{l}1 \text { if the percentage is greater than } \\
25 \% ; 0 \text { otherwise } \\
1 \text { if the percentage is greater than } \\
25 \% ; 0 \text { otherwise } \\
1 \text { if the company has a single } \\
\text { shareholder with } 20 \% \text { ownership; } 0 \\
\text { otherwise }\end{array}$ & $\begin{array}{l}\text { If the total equals to } 0 \text { or } 1 \text {, } \\
\text { the company is considered to } \\
\text { have dispersed ownership, If } \\
\text { the total equals to } 2 \text { or } 3 \text { the } \\
\text { company is considered to } \\
\text { have concentrated ownership }\end{array}$ \\
\hline \multicolumn{3}{|c|}{ Board effectiveness } \\
\hline $\begin{array}{l}\text { IND_DIRE } \\
\text { OUTS_DIR }\end{array}$ & $\begin{array}{l}1 \text { if the board size is equal to or } \\
\text { greater than } 12^{1} ; 0 \text { otherwise } \\
1 \text { if the CEO and the chairman is } \\
\text { separate; } 0 \text { otherwise } \\
1 \text { if the company has } 75 \% \text { or more } \\
\text { independent directors from the total } \\
\text { board members }{ }^{1} ; 0 \text { otherwise } \\
1 \text { if the company has } 75 \% \text { or more } \\
\text { independent director from the total } \\
\text { board members; } 0 \text { otherwise }\end{array}$ & $\begin{array}{l}\text { If the total equals to } 3 \text { or } 4 \text {, } \\
\text { the company is considered to } \\
\text { have high board } \\
\text { effectiveness; and if the total } \\
\text { is } 0,1 \text { or } 2 \text {, the company is } \\
\text { considered to have low board } \\
\text { effectiveness. }\end{array}$ \\
\hline \multicolumn{3}{|c|}{ Financial transparency and disclosures } \\
\hline $\begin{array}{l}\text { AUD_QUALITY } \\
\text { AUD_OP }\end{array}$ & $\begin{array}{l}1 \text { if the audit committee is chaired by } \\
\text { an independent director; } 0 \text { otherwise } \\
1 \text { if the company received } \\
\text { unqualified opinion; } 0 \text { otherwise }\end{array}$ & $\begin{array}{l}\text { If the total equals to } 2 \text { the } \\
\text { company is considered to } \\
\text { have high financial } \\
\text { transparency; if the total } \\
\text { equals to } 1 \text { or } 0 \text { the company } \\
\text { is considered to have low } \\
\text { financial transparency }\end{array}$ \\
\hline \multicolumn{3}{|l|}{ Shareholder rights } \\
\hline $\begin{array}{l}\text { EX_AUDITOR } \\
\text { REM_MGT }\end{array}$ & $\begin{array}{l}1 \text { if shareholders appoint the external } \\
\text { auditor; } 0 \text { otherwise } \\
1 \text { if shareholders approve the } \\
\text { remuneration of the executive } \\
\text { management; } 0 \text { otherwise }\end{array}$ & $\begin{array}{l}\text { If the total equals to } 2 \text { the } \\
\text { company is considered to } \\
\text { have high shareholder rights; } \\
\text { if the total equals to } 1 \text { or } 0 \text { the } \\
\text { company is considered to } \\
\text { have low shareholder rights }\end{array}$ \\
\hline
\end{tabular}

\footnotetext{
${ }^{1}$ The criteria are consistent with S\&P corporate governance survey (2012) results.
} 


\section{TABLE 3}

\section{Descriptive Statistics and Correlation among Z-Score Variables}

The sample consists of 835 firm-year observations (160 default firms and 675 non-default firms) for the period of 2000-2015. The Z-score components are defined as: WC/TA= Working capital/ Total assets, MVE/TL= Market value of equity/ Total liabilities, S/TA= Sales/ Total assets, RE/TA $=$ Retained earnings/ Total assets, and EBIT/TA $=$ Earnings before interest and tax/ Total assets. This table shows the mean, standard deviation (Std. Dev.), T-statistics and the significant of T-values.

Panel A: Descriptive statistics of Z-score values

\begin{tabular}{ccccccc}
\hline & \multicolumn{2}{c}{$\begin{array}{c}\text { Default firms } \\
(\mathbf{N = 1 6 0 )}\end{array}$} & \multicolumn{2}{c}{$\begin{array}{c}\text { Non-default firms } \\
(\mathbf{N = 6 7 5 )}\end{array}$} & \multicolumn{2}{c}{ Test of equal means } \\
\hline & Mean & Std. Dev. & Mean & Std. Dev. & T-value & P-value \\
WC/TA & 0.07 & 1.16 & .12 & 0.17 & -1.19 & 0.23 \\
MVE/TL & 6.60 & 16.53 & 198.99 & 2042.43 & -1.19 & 0.23 \\
S/TA & 1.15 & 1.07 & 0.85 & 0.58 & 4.88 & 0.00 \\
RE/TA & -4.65 & 10.61 & 0.32 & 0.32 & -12.16 & 0.00 \\
EBIT/TA & -0.81 & 3.83 & 0.13 & 0.08 & -6.39 & 0.00 \\
\hline
\end{tabular}

Panel B: Correlation matrix for $\mathrm{Z}$-score variables

\begin{tabular}{lrrrrr}
\hline Variables & WC/TA & MVE/TL & S/TA & RE/TA & EBIT/TA \\
\hline WC/TA & 1.00 & & & & \\
MVE/TL & -0.01 & 1.00 & & & \\
S/TA & -0.12 & -0.07 & 1.00 & & \\
RE/TA & 0.17 & 0.01 & -0.03 & 1.00 & \\
EBIT/TA & 0.06 & 0.001 & -0.15 & 0.32 & 1.00 \\
\hline
\end{tabular}




\section{TABLE 4 \\ Descriptive Statistics and Correlation among Governance Variables}

The sample consists of 835 firm-year observations (160 default firms and 675 non-default firms) for the period of 2000-2015. The variables are defined as: INST (\%)=Institutional share ownership, FIVE_SH= Shareholding by five largest shareholders, BLOCK_20= A dummy variable for the presence of block shareholder with at least $20 \%$ of shareholding, EXT_AUD= shareholder rights to appoint external auditor, REM_MAG= shareholder rights to approve remuneration of executive management, AUDCOM_QUA= audit committee quality, AUD_OP=auditor opinion, BOARD SIZE, CEO DUALITY, IND_DIRE= number of independent directors in the board, OUT_DIRE= number of outside directors in the board. Panel A shows the mean, standard deviation (Std. Dev.), T-statistics and the significant of Tvalues and panel B reports the coefficients for Pearson's correlation among governance variables.

Panel A: Descriptive statistics for governance variables

\begin{tabular}{lcccccc}
\hline & \multicolumn{2}{c}{$\begin{array}{c}\text { Default firms } \\
\text { Me160) }\end{array}$} & \multicolumn{2}{c}{$\begin{array}{c}\text { Non-default firms } \\
\text { M=675) }\end{array}$} & \multicolumn{2}{c}{ Test of equal means } \\
& M.D & Mean & S.D & t-value & P-value \\
\hline $\begin{array}{l}\text { Ownership structure and influence } \\
\text { INS }\end{array}$ & 37.258 & 25.368 & 21.270 & 27.354 & 6.738 & 0.000 \\
FIVE_SH & 50.853 & 24.039 & 26.278 & 28.307 & 10.147 & 0.000 \\
BLOCK_20 & 0.425 & 0.496 & 0.240 & 0.427 & 4.768 & 0.000 \\
Board effectiveness & & & & & & \\
BOARD_SIZE & 6.450 & 2.040 & 12.671 & 3.955 & -19.293 & 0.000 \\
CEO_DUA & 0.519 & 0.501 & 0.609 & 0.488 & -2.089 & 0.037 \\
IND_DIRE & 4.375 & 2.012 & 9.116 & 3.679 & -15.745 & 0.000 \\
OUTS_DIRE & 4.613 & 2.113 & 9.679 & 3.755 & -16.453 & 0.000 \\
Financial transparency and disclosures & & & & & \\
AUD_QUALITY & 0.931 & 0.254 & 0.987 & 0.115 & -4.160 & 0.000 \\
AUD_OP & 0.263 & 0.441 & 0.630 & 0.483 & -8.780 & 0.000 \\
Shareholder rights & & & & & & \\
EX_AUDITOR & 0.956 & 0.205 & 1.000 & 0.000 & -5.551 & 0.000 \\
REM_MGT & 0.556 & 0.498 & 0.554 & 0.497 & 0.050 & 0.960 \\
\hline
\end{tabular}


Panel B: Co-efficient for Pearson's Correlation Matrix for Corporate Governance Variables

\begin{tabular}{|c|c|c|c|c|c|c|c|c|c|c|c|}
\hline & $\begin{array}{l}\text { INST } \\
(\%)\end{array}$ & FIVE_SH & $\begin{array}{c}B L O C K \\
\quad 20\end{array}$ & $\begin{array}{c}E X T_{-} A U \\
D\end{array}$ & $\underset{G}{R E M \_M A}$ & $\begin{array}{c}A U D C O M_{-} \\
Q U A\end{array}$ & $A U D \_O P$ & $\begin{array}{c}\text { BOARD } \\
\text { SIZE }\end{array}$ & $\begin{array}{c}C E O \\
D U A L I T Y\end{array}$ & ${ }_{E}^{I N D \_D I R}$ & $\begin{array}{c}O U T_{-} D I R \\
E\end{array}$ \\
\hline $\operatorname{INST}(\%)$ & 1.00 & & & & & & & & & & \\
\hline FIVE_SH & 0.68 & 1.00 & & & & & & & & & \\
\hline BLOCK_20 & 0.45 & 0.75 & 1.00 & & & & & & & & \\
\hline$E X T \_A U D$ & -0.02 & -0.10 & -0.09 & 1.00 & & & & & & & \\
\hline$R E M \_M A G$ & -0.04 & -0.07 & -0.11 & 0.05 & 1.00 & & & & & & \\
\hline$A U D C O M \_Q U A$ & -0.03 & -0.08 & -0.11 & -0.01 & 0.05 & 1.00 & & & & & \\
\hline$A U D \_O P$ & 0.02 & -0.03 & -0.04 & 0.08 & 0.06 & 0.07 & 1.00 & & & & \\
\hline BOARD SIZE & 0.01 & -0.20 & -0.16 & 0.11 & -0.05 & 0.16 & 0.16 & 1.00 & & & \\
\hline CEO DUALITY & -0.22 & -0.28 & -0.20 & 0.03 & -0.16 & 0.04 & -0.05 & -0.04 & 1.00 & & \\
\hline IND_DIRE & -0.20 & -0.44 & -0.42 & 0.10 & -0.01 & 0.20 & 0.16 & 0.72 & -0.003 & 1.00 & \\
\hline OUT_DIRE & -0.15 & -0.34 & -0.32 & 0.10 & 0.03 & 0.20 & 0.17 & 0.78 & -0.05 & 0.90 & 1.00 \\
\hline
\end{tabular}

This article is protected by copyright. All rights reserved. 


\section{TABLE 5}

\section{Default Correlation over Short and Long Time Horizon}

This table presents the estimates of default correlations for various credit qualities over one, five and ten-year time horizons. Default correlations are calculated by using Equation (1) for each pair of firms. T-statistics are in parentheses. $* * *$ and $* *$ represent significance at $1 \%$ and $5 \%$, respectively. The sample consists of 835 firm-year observations (160 default firms and 675 non-default firms) for the period of 2000-2015. Five-year and ten-year time horizons indicate that five years and ten years following the default year respectively.

\begin{tabular}{|c|c|c|c|c|}
\hline $\begin{array}{l}\text { Time } \\
\text { Horizon }\end{array}$ & Credit quality & \multicolumn{3}{|c|}{ Credit quality } \\
\hline \multirow{3}{*}{ One year } & & High Grade & Medium Grade & Low Grade \\
\hline & High Grade & $2.80 \%(2.44)^{* *}$ & & \\
\hline & Medium Grade & $3.24 \%(2.06)^{* *}$ & $1.66 \%(0.39)$ & \\
\hline \multirow{4}{*}{ Five year } & Low Grade & $6.39 \%(5.45)^{* * *}$ & $7.19 \%(3.13)^{* * *}$ & $12.15 \%(5.29)^{* * *}$ \\
\hline & High Grade & $23.73 \%(23.84)^{* * *}$ & & \\
\hline & Medium Grade & $29.33 \%(24.43)^{* * *}$ & $34.62 \%(11.11)^{* * *}$ & \\
\hline & Low Grade & $29.27 \%(44.34)^{* * *}$ & $33.84 \%(29.97)^{* * *}$ & $56.97 \%(64.88)^{* * *}$ \\
\hline \multirow{3}{*}{ Ten year } & High Grade & $34.95 \%(32.90)^{* *}$ & & \\
\hline & Medium Grade & $40.78 \%(35.29) * *$ & $48.48 \%(19.22)^{* *}$ & \\
\hline & Low Grade & $40.42 \%(68.29)^{* *}$ & $50.62 \%(55.39)^{* *}$ & $69.61 \%(104.49)^{* *}$ \\
\hline
\end{tabular}




\section{TABLE 6 \\ Corporate Governance and Default Correlation}

This table reports the default correlations among different credit qualities under four corporate governance dimensions (Ownership structure and influence, Board effectiveness, Financial transparency and disclosures and shareholder rights). Default correlations are calculated by using Equation (1) for each pair of firms. T-statistics are in parentheses. *** represents significance at $1 \%$. The sample consists of 835 firm-year observations (160 default firms and 675 non-default firms) for the period of 2000-2015.

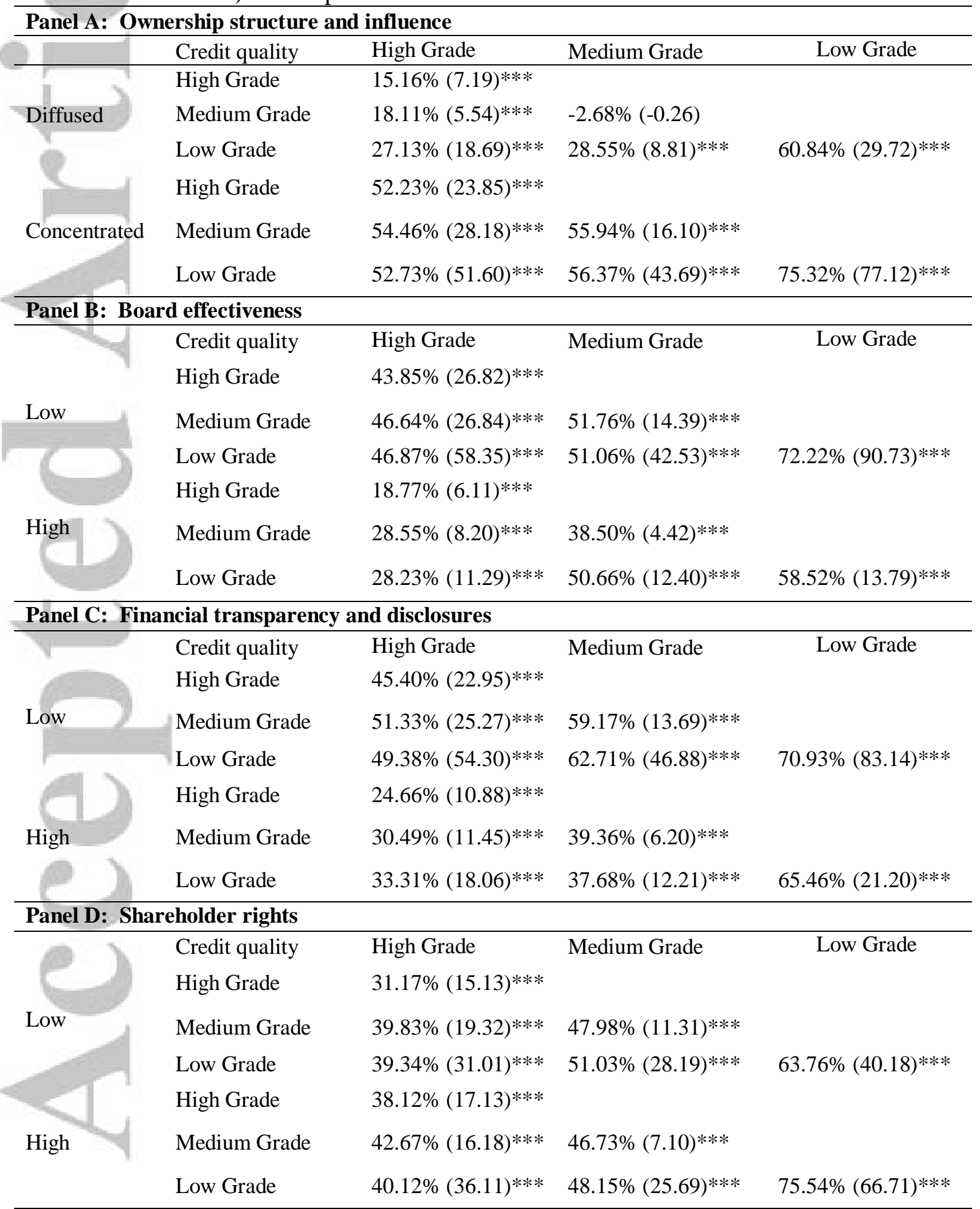

This article is protected by copyright. All rights reserved. 
TABLE 7

Default Correlation: Good and Poor Corporate Governance Effect in Crisis and Non-Crisis period

This table reports the default correlations among poor and good corporate governance firms in crisis and non-crisis periods. Poor corporate governance defined as concentrated ownership, low board effectiveness, low financial transparency, and high shareholder rights. Default correlations are calculated by using Equation (1) for each pair of firms. T-statistics are in parentheses. $* * *$ represents significance at $1 \%$. The sample consists of 835 firm-year observations (160 default firms and 675 non-default firms) for the period of 2000-2015.

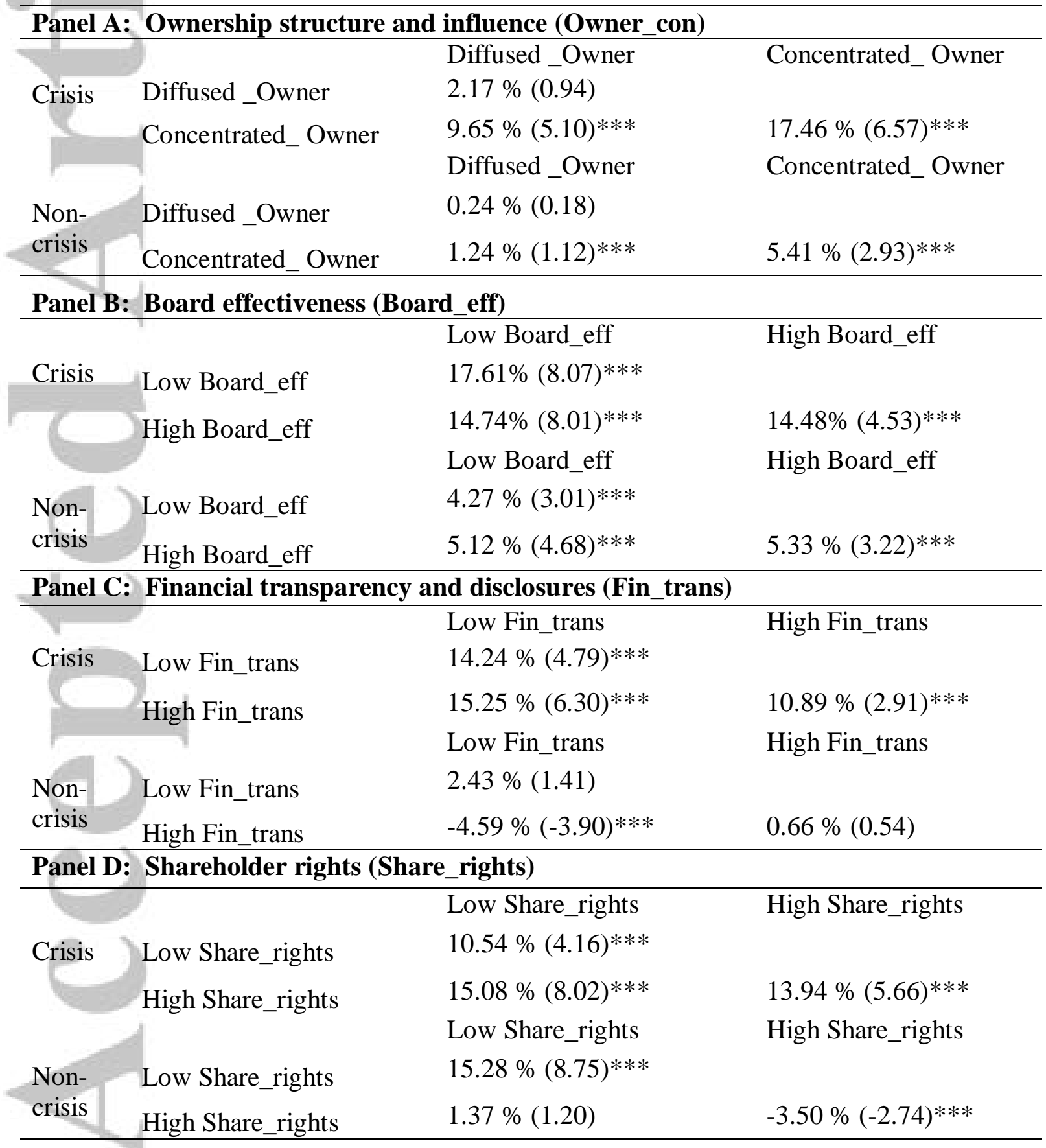




\title{
Author's Biographies
}

\author{
Jayasuriya Mahapatabendige Ruwani Fernando
}

Dr. Fernando is a Senior Lecturer attached to the Department of Finance, Faculty of Commerce and Management Studies, University of Kelaniya, Sri Lanka. She was a recipient of the Commonwealth Scholarship granted by the Ministry of Foreign Affairs and Trade, New Zealand in 2016. She has completed her Ph.D. in Finance at the University of Waikato, New Zealand in 2019. Her research expertise areas in finance are risk management, Corporate governance, and corporate finance.

\section{Leon $\mathrm{Li}$}

$\mathrm{Dr} \mathrm{Li}$ is an Associate Professor of Finance and Subject Convenor, Finance, at the School of Accounting, Finance and Economics of the University of Waikato, New Zealand. Dr Li's research program focuses on risk management, corporate finance, and behavioral finance. He has sole-authored and coauthored with many researchers which resulted in more than 50 publications. Many of those articles appeared at the mainstream Finance and Accounting journals including Journal of Behavioral Finance, Journal of International Financial Management and Accounting, British Accounting Review, Abacus, Journal of Banking and Finance, and Journal of Empirical Finance to name a few.

$$
\text { Yang (Greg) Hou }
$$

Dr Yang (Greg) Hou is a Senior Lecturer of Finance at the School of Accounting, Finance and Economics of the University of Waikato, New Zealand. Dr Greg's research interest is asset pricing, applied financial econometrics, risk analysis and management, derivatives markets and energy finance. He has coauthored with some researchers in the fields which resulted in around 10 publications. Some of those articles appeared at the journals such as Pacific Basin Finance Journal, International Review of Economics and Finance, Energy Economics, Australian Journal of Management, and Economic Modelling.

\section{Acknowledgment}

We thank the Editor-in-Chief of the Journal, Professor Prof. Konstantinos Stathopoulos, and two anonymous referees for their useful comments to improve the quality of the paper. We also thank MFATNZ for the financial support provided to Ruwani for her Ph.D. 


\section{Endnotes}

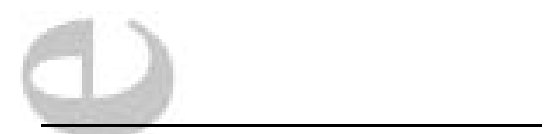

i See Lucas (1995) for real world examples of the contagion effect.

ii Jorion and Zhang (2007) follow Lang and Stulz (1992) in their selection of variables to measure the contagion effect.

iii Ashbaugh-Skaife et al. (2006) argue that, under the wealth distribution hypothesis, when the percentage of share ownership by institutions increases, it affects the wealth transfer to bondholders. They suggest a negative relationship between institution share ownership and credit ratings.

iv According to Ashbaugh-Skaife et al. (2006), the management disciplining hypothesis holds that the primary role of corporate governance is to curb managerial opportunism.

${ }^{v}$ According to the wealth distribution hypothesis, the role of governance mechanisms is to ensure the wealth distribution among all stakeholders.

${ }^{\text {vi }}$ Studies show that board diversity is important for board effectiveness (e.g. Rose, 2007). We therefore suggest that studies in the future consider the presence of female board members as evidence of board diversity which should thus prompt an examination of the firm's default correlation.

vii The Advisory Committee on the Auditing Profession (ACAP), appointed by the U.S. Department of Treasury, recommends that public companies make use of shareholder voting to ratify the auditor appointment.

viii The say-on-pay legislation was included in the Dodd-Frank Wall Street Reform and Consumer Protection Act in 2010. However, we consider the variable in our study as we cover the time period from 2000 to 2015.

${ }^{\text {ix }}$ Wruck (1989) uses three levels of ownership concentrations, that is, low concentration (0-5\%), middle range of ownership concentration (5\%-25\%), and high concentration (above $25 \%$ ), to find the effect of private equity sales announcements on firm value due to the changes of ownership concentration.

${ }^{x}$ These criteria are decided based on the results of the S\&P governance survey (2016). The survey provides the averages of the governance variables based on the S\&P 500 companies in the U.S. The average values are taken as benchmarks in deciding the threshold of those variables.

xi The threshold is decided by dividing the sum of the index equally and zero is obviously categorized as low board effectiveness.

xii The Compustat database defines unqualified opinion in the following way: "there are no unresolvable restrictions in company financial statements and the auditor has no significant exceptions as to the accounting principles, the consistency of their application, and the adequacy of information disclosed".

xiii Even though the two variables show a higher correlation, the study retains the two variables due to the different roles of independent and outside direstors in the governing mechanism.

${ }^{\text {xiv }}$ Ashbaugh-Skaife et al. (2006) measure shareholder rights by using the governance index of Gomper et al. (2003), where they found a positive association between the governance index and credit ratings. A higher score in the governance index indicates weaker shareholder rights.

$x v$ Although the robustness tests are reported as untabulated, the tables are available for readers upon request and reported as supplementary information in a separate file in our submission to the journal.

xvi This classification is closely related to Moody's interpretation for S\&P credit ratings. For example, S\&P's high credit quality range from AAA to A- is matched to the band encompassing minimal credit risk to low credit risk in Moody's interpretation.

xvii All the results relating to higher credit quality and governance attributes show a zero correlation because none of the default firms have secured higher credit ratings and do not belong in the high credit quality category. xviii Financial expertise is defined as the audit committee member having a CPA or being a CFO.

xix The data for GOV_INDEX is available on Andrew Metric's website: http://faculty.som.yale.edu/andrewmetrick/data.html. The data for this score stops in the year 2006. Thus, for this analysis, we limit our sample firms to those from the year 2000 through to 2006, which resulted in 437 firms. 


\section{REFERENCES}

Aharony, J., \& Swary, I. (1983). Contagion effects of bank failures: Evidence from capital markets. Journal of Business, 56: 305-322.

Altman, E.I. (1968). Financial ratios, discriminant analysis and the prediction of corporate bankruptcy. The Journal of Finance, 23: 589-609. https://doi.org/10.1111/j.15406261.1968.tb00843.x

Altman, E. I., \& McGough, T. P. (1974). Evaluation of a company as a going concern. Journal of Accountancy, 138: 50-57. Retrieved from http://search.ebscohost.com.ezproxy.waikato.ac.nz/login.aspx?direct=true\&db=bth\& $\mathrm{AN}=4570288 \&$ site $=$ ehost-live

Ashbaugh-Skaife, H., Collins, D. W., \& LaFond, R. (2006). The effects of corporate governance on firms' credit ratings. Journal of Accounting and Economics, 42: 203 243. https://doi.org/10.1016/j.jacceco.2006.02.003

Bédard, J., Chtourou, S. M., \& Courteau, L. (2004). The effect of audit committee expertise, independence, and activity on aggressive earnings management. Auditing: A Journal of Practice \& Theory, 23: 13-35. https://doi.org/10.2308/aud.2004.23.2.13

Bascle, G. (2008). Controlling for endogeneity with instrumental variables in strategic $\begin{array}{lllll}\text { management } & \text { research. } & \text { Strategic }\end{array}$ https://doi.org/10.1177/1476127008094339

Bhojraj, S., \& Sengupta, P. (2003). Effect of corporate governance on bond ratings and yields: The role of institutional investors and outside directors. The Journal of Business, 76: 455-475. https://doi.org/10.1086/344114

Black, F., \& Cox, J. C. (1976). Valuing corporate securities: Some effects of bond indenture provisions. The Journal of Finance, 31: 351-367. https://doi.org/10.1111/j.15406261.1976.tb01891.x

Bradshaw, M. T., Richardson, S. A., \& Sloan, R. G. (2001). Do analysts and auditors use information in accruals?. Journal of Accounting Research, 39: 45-74. https://doi.org/10.1111/1475-679X.00003

Chava, S., Livdan, D. \& Purnanandam, A. (2008). Do shareholder rights affect the cost of bank loans? The Review of Financial Studies, 22: 2973-3004. https://doi.org/10.1093/rfs/hhn111 
Cohen, J., Krishnamoorthy, G., \& Wright, A. (2010). Corporate governance in the postSarbanes-Oxley era: Auditors' experiences. Contemporary Accounting Research, 27: 751-786. https://doi.org/10.1016/j.jacceco.2014.08.006

Claessens, S., Djankov, S., \& Lang, L. H. (2000). The separation of ownership and control in East Asian corporations. Journal of Financial Economics, 58: 81-112. https://doi.org/10.1016/S0304-405X(00)00067-2

Coffee, J. C. (2006). Gatekeepers: The professions and corporate governance. Oxford, United Kingdom: Oxford University Press.

Core, J. E., Holthausen, R. W., \& Larcker, D. F. (1999). Corporate governance, chief executive officer compensation, and firm performance. Journal of Financial Economics, 51: 371-406. https://doi.org/10.1016/S0304-405X(98)00058-0

Crouhy, M., Galai, D., \& Mark, R. (2000). A comparative analysis of current credit risk models. Journal of Banking \& Finance, 24: 59-117. https://doi.org/10.1016/S03784266(99)00053-9

Daily, C. M., \& Dalton, D. R. (1994). Bankruptcy and corporate governance: The impact of board composition and structure. Academy of Management Journal, 37: 1603-1617. https://doi.org/10.5465/256801

Dalton, D. R., \& Kesner, I. F. (1987). Composition and CEO duality in boards of directors: An international perspective. Journal of International Business Studies, 18: 33-42. https://doi.org/10.1057/palgrave.jibs.8490410.

Dao, M., Raghunandan, K., \& Rama, D. V. (2012). Shareholder voting on auditor selection, audit fees, and audit quality. The Accounting Review, 87: 149-171. https://doi.org/10.2308/accr-10159

Das, S. R., Duffie, D., Kapadia, N., \& Saita, L. (2007). Common failings: How corporate defaults are correlated. The Journal of Finance, 62: 93-117. https://doi.org/10.1111/j.1540-6261.2007.01202.x

Das, S., Freed, L., Geng, G., \& Kapadia, N. (2006). Correlated default risk. The Journal of Fixed Income, 16: 7-32. https://doi.org/10.3905/jfi.2006.656006

Davis, S. (2007). Does ‘say on pay’work? Lessons on making CEO compensation accountable. $\begin{array}{lllll}\text { Policy } & \text { Briefing, } & \text { Retrieved } & \text { from }\end{array}$ http://www.shareholderforum.com/op/Library/20070620_Davis-briefing.pdf

Deane, S. (2007). Say on pay: results from overseas. Corporate Board, 28: 11-18. 
Dechow, P.M., \& Skinner, D.J. (2000). Earnings management: Reconciling the views of accounting academics, practitioners, and regulators. Accounting Horizons, 14: 235250. https://doi.org/10.2308/acch.2000.14.2.235

De Servigny, A., \& Renault, O. (2002). Default correlation: Empirical evidence. Standard and Poor's.

Retrieved

from https://www.researchgate.net/profile/Olivier_Renault2/publication/228679968_Defaul t_correlation_Empirical_evidence/links/00b4951aa5379eff1d000000.pdf

Duffie, D. (1998). First-to-default valuation. Working paper Graduate school of Business, Stanford University, CA.

Duffie, D., Pedersen, L. H., \& Singleton, K. J. (2003). Modelling sovereign yield spreads: A case study of Russian debt. The Journal of Finance, 58: 119-159. https://doi.org/10.1111/1540-6261.00520

Duffie, D., Saita, L., \& Wang, K. (2007). Multi-period corporate default prediction with stochastic covariates. Journal of Financial Economics, 83: 635-665. https://doi.org/10.1016/j.jfineco.2005.10.011

Elloumi, F., \& Gueyie, J. P. (2001). Financial distress and corporate governance: An empirical analysis. Corporate Governance: The International Journal of Business in Society, 1: 15-23. https://doi.org/10.1108/14720700110389548

Erkens, D. H., Hung, M., \& Matos, P. (2012). Corporate governance in the 2007-2008 financial crisis: Evidence from financial institutions worldwide. Journal of Corporate Finance, 18, 389-411. https://doi.org/10.1016/j.jcorpfin.2012.01.005

Fernando, J. M. R., Li, L., \& Hou, Y. (2019). Corporate governance and default prediction: A $\begin{array}{llll}\text { reality test. Applied } & \text { Economics, }\end{array}$ https://doi.org/10.1080/00036846.2018.1558351

FitchRatings. (2004). Credit policy special report, evaluating corporate governance: The bondholder's perspective. New York: FitchRatings.

Francis, J. R., \& Krishnan, J. (1999). Accounting accruals and auditor reporting conservatism. Contemporary Accounting Research, 16: 135-165. https://doi.org/10.1111/j.19113846.1999.tb00577.x

Galai, D., \& Masulis, R. W. (1976). The option pricing model and the risk factor of stock. Journal of Financial Economics, 3: 53-81. https://doi.org/10.1016/0304405X(76)90020-9

Gersbach, H., \& Lipponer, A. (2003). Firm defaults and the correlation effect. European Financial Management, 9: 361-378. https://doi.org/10.1111/1468-036X.00225

This article is protected by copyright. All rights reserved. 
Geske, R. (1977). The Valuation of corporate liabilities as compound options. Journal of Financial and Quantitative Analysis, 12: 541-552. https://doi.org/10.2307/2330330

Giesecke, K. (2004). Correlated default with incomplete information. Journal of Banking \& Finance, 28: 1521-1545. https://doi.org/10.1016/S0378-4266(03)00129-8

Gompers, P., Ishii, J., \& Metrick, A. (2003). Corporate governance and equity prices. The Quarterly of Journal Economics, 118: 107-156. https://doi.org/10.1162/00335530360535162

Harris, M., \& Raviv, A. (2006). A theory of board control and size. The Review of Financial Studies, 21: 1797-1832.

Healy, P. M., \& Wahlen, J. M. (1999). A review of the earnings management literature and its implications for standard setting. Accounting Horizons, 13: 365-383. https://doi.org/10.2308/acch.1999.13.4.365

Hermalin, B. E., \& Weisbach, M. S. (1998). Endogenously chosen boards of directors and their monitoring of the CEO. American Economic Review, 88: 96-118.

Jarrow, R. A., \& Yu, F. (2001). Counterparty risk and the pricing of defaultable securities. The Journal of Finance, 56: 1765-1799. https://doi.org/10.1111/0022-1082.00389

Jensen, M. C., \& Meckling, W. H. (1976). Theory of the firm: Managerial behavior, agency costs and ownership structure. Journal of Financial Economics, 3: 305-360. https://doi.org/10.1016/0304-405X(76)90026-X

Johnson, S., Boone, P., Breach, A., \& Friedman, E. (2000). Corporate governance in the Asian financial crisis. Journal of Financial Economics, 58: 141-186. https://doi.org/10.1016/S0304-405X(00)00069-6

Jorion, P., \& Zhang, G. (2007). Good and bad credit contagion: Evidence from credit default swaps. Journal of Financial Economics, 84: 860-883. https://doi.org/10.1016/j.jfineco.2006.06.001

Keenan, S.C., Hamilton, D.T., \& Berthault, A. (2000). Historical default rates of corporate bond issuers, 1920-1999. Moody's Investors Services. Retrieved from http://s3.amazonaws.com/zanran_storage/www.moodyskmv.com/ContentPages/191918 94.pdf

Klein, A. (2002). Audit committee, board of director characteristics, and earnings management. Journal of Accounting and Economics,33: 375-400. https://doi.org/10.1016/S0165-4101(02)00059-9 
Klock, M. S., Mansi, S. A., \& Maxwell, W. F. (2005). Does corporate governance matter to bondholders? Journal of Financial and Quantitative Analysis, 40: 693-719. https://doi.org/10.1017/S0022109000001940

Lang, L. H., \& Stulz, R. (1992). Contagion and competitive intra-industry effects of bankruptcy announcements: An empirical analysis. Journal of Financial Economics, 32: 45-60. https://doi.org/10.1016/0304-405X(92)90024-R

La Porta, R., Lopez-de-Silanes, F., \& Shleifer, A. (1999). Corporate ownership around the world. The Journal of Finance, 54: 471-517. https://doi.org/10.1111/00221082.00115

Lemmon, M. L., \& Lins, K. V. (2003). Ownership structure, corporate governance, and firm value: Evidence from the East Asian financial crisis. The Journal of Finance, 58: 14451468. https://doi.org/10.1111/1540-6261.00573

Lensberg, T., Eilifsen, A., \& McKee, T. E. (2006). Bankruptcy theory development and classification via genetic programming. European Journal of Operational Research, 169: 677-697. https://doi.org/10.1016/j.ejor.2004.06.013

Li, D. X. (2000). On default correlation: A copula function approach. The Journal of Fixed Income, 9: 43-54. https://doi.org/10.2139/ssrn.187289

Li, L., \& Chen, C. (2018). The domino effect of credit defaults: test of asymmetric default correlations using realized default data. Applied Economics, 50: 4803-4813. https://doi.org/10.1080/00036846.2018.1467553

Lipton, M., \& Lorsch, J. W. (1992). A modest proposal for improved corporate governance. The Business Lawyer, 48: 59-77.

Lorsch, J. W. (1989). Pawns or potentates: The reality of America's corporate boards, Boston: Harvard Business School Press.

Lucas, D. J. (1995). Default correlation and credit analysis. The Journal of Fixed Income, 4: 76-87. https://doi.org/10.3905/jfi.1995.408124

Mayhew, B. W., \& Pike, J. E. (2004). Does investor selection of auditors enhance auditor $\begin{array}{lllll}\text { independence? } & \text { The }\end{array}$ https://doi.org/10.2308/accr.2004.79.3.797

Merton, R. C. (1974). On the pricing of corporate debt: The risk structure of interest rates. The Journal of Finance, 29: 449-470. https://doi.org/10.1111/j.1540-6261.1974.tb03058.x 
Parker, S., Peters, G. F., \& Turetsky, H. F. (2002). Corporate governance and corporate failure: A survival analysis. Corporate Governance: The International Journal of Business in Society, 2: 4-12. https://doi.org/10.1108/14720700210430298

Pathan, S. (2009). Strong boards, CEO power and bank risk-taking. Journal of Banking \& Finance, 33: 1340-1350. https://doi.org/10.1016/j.jbankfin.2009.02.001

Pfeffer, J. (1972). Size and composition of corporate boards of directors: The organization and its environment. Administrative Science Quarterly, 17: 218-228. https://doi.org/10.2307/2393956

Pfeffer, J., \& Salancik, G. R. (1978). The external control of organizations: A resource dependence approach. New York: Harper and Row Publishers. https://doi.org/10.1016/j.jbusres.2011.08.003

Platt, H., \& Platt, M. (2012). Corporate board attributes and bankruptcy. Journal of Business Research, 65: 1139-1143. https://doi.org/10.1016/j.jbusres.2011.08.003

Raheja, C. G. (2005). Determinants of board size and composition: A theory of corporate boards. Journal of financial and quantitative analysis, 40: 283-306. https://doi.org/10.1017/S0022109000002313

Rose, C. (2007). Does female board representation influence firm performance? The Danish evidence. Corporate Governance: An International Review, 15: 404-413. https://doi.org/10.1111/j.1467-8683.2007.00570.x

Sengupta, P. (1998). Corporate disclosure quality and the cost of debt. Accounting Review, 73 : 459-474.

Shleifer, A., \& Vishny, R. W. (1997). A survey of corporate governance. The Journal of Finance, 52: 737-783. https://doi.org/10.1111/j.1540-6261.1997.tb04820.x

Simpson, W. G., \& Gleason, A. E. (1999). Board structure, ownership, and financial distress in banking firms. International Review of Economics and Finance, 8: 281-292. https://doi.org/10.1016/S1059-0560(99)00026-X

Standard \& Poor's (2002). Standard \& Poor's Corporate Governance Scores: Criteria, Methodology and Definitions. New York: McGraw-Hill Companies, Inc.

Switzer, L. N., \& Wang, J. (2013). Default risk estimation, bank credit risk, and corporate governance. Financial Markets, Institutions \& Instruments, 22: 91-112. https://doi.org/10.1111/fmii.12005

Switzer, L. N., Tu, Q., \& Wang, J. (2018). Corporate governance and default risk in financial firms over the post-financial crisis period: International evidence. Journal of 
International Financial Markets, Institutions and Money, 52: 196-210. https://doi.org/10.1016/j.intfin.2017.09.023

Wintoki, M. B., Linck, J. S., \& Netter, J. M. (2012). Endogeneity and the dynamics of internal corporate governance. Journal of Financial Economics, 105: 581-606. https://doi.org/10.1016/j.jfineco.2012.03.005

Wruck, K. H. (1989). Equity ownership concentration and firm value: Evidence from private equity financings. Journal of Financial Economics, 23: 3-28. https://doi.org/10.1016/0304-405X(89)90003-2

Zahra, S. A., \& Pearce, J. A. (1989). Boards of directors and corporate financial performance: A review and integrative model. Journal of Management, 15: 291-334. https://doi.org/10.1177/014920638901500208

Zhou, C. (2001). An analysis of default correlations and multiple defaults. The Review of Financial Studies, 14: 555-576. https://doi.org/10.1093/rfs/14.2.555 